DOI: $10.2478 / \mathrm{v} 10047-008-0007-5$

PHYSICS OF COSMIC RADIATION

\title{
COSMIC RAY NUCLEONIC INTENSITY IN LOW-AMPLITUDE DAYS DURING THE PASSAGE OF HIGH-SPEED SOLAR WIND STREAMS
}

\author{
Rekha Agarwal \\ Department of Physics, Govt. Model Science College (Autonomous), \\ Jabalpur (M.P.) 482 001, INDIA \\ Rajesh K. Mishra, Sharad Tiwari
}

Computer and Information Technology Section, Tropical Forest Research Institute, P.O.: RFRC, Mandla Road, Jabalpur (M.P.) 482 021, INDIA e-mail: rkm_30@yahoo.com orrm_jbp@yahoo.co.in

\begin{abstract}
One of the most striking features of solar wind is its organization into highand low- speed streams. It is now well established that the passage over the Earth of high-speed solar wind streams leads to geomagnetic disturbances. The high-speed plasma streams are thus a key element in the complex chain of events that link geomagnetic activity to the solar activity and are therefore of great interest to the solar terrestrial physics. Two types of high-speed solar wind streams - coronal-holeassociated (or corotating) and flare-generated - were studied based on magnetic field and solar wind plasma parameters. In the work, the dependence was obtained for cosmic ray (CR) depressions due to high-speed solar wind streams during lowamplitude days. The CR nucleonic intensity data were subjected to the superposed epoch analysis with respect to the start time of high-speed solar wind streams. It was found that streams of both types produce significant deviations in the CR intensity during low-amplitude anisotropic wave train events. At the onset of such streams the $\mathrm{CR}$ intensity reaches its minimum during low-amplitude events and then increases statistically.
\end{abstract} wind.

Key words: cosmic ray, corotating streams, flare-generated streams, solar

\section{INTRODUCTION}

A high-speed plasma stream is characterized by a large increase in the solar wind intensity lasting for several days. Although the average speed time profile of a high-speed plasma stream varies considerably, a plasma stream when observed by a near-Earth spacecraft usually has a well-defined leading edge with a steep velocity increase. The enhancement or subsidence of both high-speed solar wind streams (HSSWS) and the galactic cosmic rays in the minimum or the maximum phase of the solar cycle are interpreted in a unified manner by the concept of geometrical evolution of the general magnetic field of corona-helio-magnetosphere system. The subsidence of HSSWS in the maximum phase is understood as a braking of the solar wind streams by the tightly closed and strong coronal field lines in the lower corona in the maximum phase.

The decrease of the galactic cosmic rays in the maximum phase (known as Forbush's negative correlation between the galactic cosmic rays and solar activity or the Forbush solar cycle modulation of the galactic cosmic rays is interpreted as a braking of galactic cosmic rays by the closed magnetic field lines at the heliopause. 
The high-speed solar wind streams lasting for several days are observed by satellites and spacecrafts. These HSSWS produce significant geomagnetic disturbances and variations in the level of cosmic ray intensity. The HSSWS are thus a key element/member in the complex chain of events that link geo-magnetic activity/cosmic ray intensity to the solar activity and are therefore, of great interest to the solar terrestrial physics community [1-4].

Two types of high-speed solar wind streams, namely, flare-generated streams (FGS) and corotating streams (CS) are found equally effective in producing cosmic ray intensity decreases. Iucci et al. [1] and Shukla et al. [5] have shown a close correspondence between the CR intensity decrease observed by high-speed streams produced by solar flares and Forbush's decreases whose amplitudes are not directly correlated with the increase in solar wind speed. These latter decreases are usually large and depend on the location of the solar flares.

Yadav et al. [6] studied the effect of two types of HSSWS on the cosmic ray intensity using the data of three neutron-monitoring stations. They reported that the CR depressions associated with coronal hole streams are much smaller than the typically Forbush-like depressions, and no spectral difference is found in the Forbush-like decreases between the periods before and after the polarity changes. Jadhav et al. [7] analyzed the behaviour of semi-diurnal anisotropy for low amplitude anisotropic wave train events (LAEs) by comparing the average semi-diurnal amplitude for each event with the 27-day or annual aver-age semi-diurnal amplitude. They found that there is no significant difference between the two wave trains. For these LAE cases the semi-diurnal amplitude is found to be normal, which shows that the diurnal and semi-diurnal anisotropies are not related with each other for these LAEs.

A number of low-amplitude events have been studied, and it was observed that the diurnal time of maximum consistently remains along the corotational direction for the majority of the events or shifts towards later/earlier hours, and the occurrence of these events was not found to depend upon the HSSWS [8-11]. The occurrence of LAE is dominant for the positively directed $\mathrm{Bz}$ component of the interplanetary magnetic field (IMF) polarity [12].

\section{DATA AND ANALYSIS}

Using the long-term plots of cosmic ray nucleonic intensity data as well as the amplitudes obtained from harmonic analysis of the cosmic ray pressure corrected hourly NM data the low-amplitude wave train events have been selected based on the following criteria:

- LAEs of continuous days - when the amplitude of diurnal anisotropy remains lower than $0.3 \%$ on each day of the event for at least five days.

- In the selection of these events, special care has been taken, i.e. if there occurred any pre-Forbush or post-Forbush decrease before or after the event or the event is in the recovery phase or declining phase they are not considered.

Based on the above criteria we have selected 29 LAE during the period 1981-1994. In the present study we analyzed the hourly CR intensity data for Deep River NM station [Geog. Lat. 46.10 (Deg.), Geog. Long. 282.50 (Deg.), Vertical cut-off rigidity $1.02(\mathrm{GV})]$. 


\section{RESULTS AND DISCUSSION}

In the analysis, we have identified two types of high-speed solar wind streams using the plots of hourly values of interplanetary parameters [13-17] to study the role of these types of streams in a LAE.

The mentioned above two types of high-speed solar wind streams - namely, corotating (or coronal-hole-associated) streams (CS) and the flare-generated streams (FGS) were identified following the criteria suggested by Mavromichalaki et al. [18]. Large Forbush's decreases in the cosmic ray intensity, if any, were excluded to avoid their influence. On the basis of the above selection criteria we have identified seven corotating streams and one flare-generated stream during 29 LAEs.

We have adopted the Chree analysis of superposed epoch to study the effect of high-speed solar wind streams on the cosmic ray nucleonic intensity using the daily average cosmic ray intensity of Deep River neutron monitor during LAE. The occurrence of two types of HSSWS during LAEs for the period 1981-1994 is in Fig. 1. It is clearly seen from this figure that the number of corotating streams is greater than that of flare generated streams and that there is a tendency for longer duration of corotating streams for LAEs.

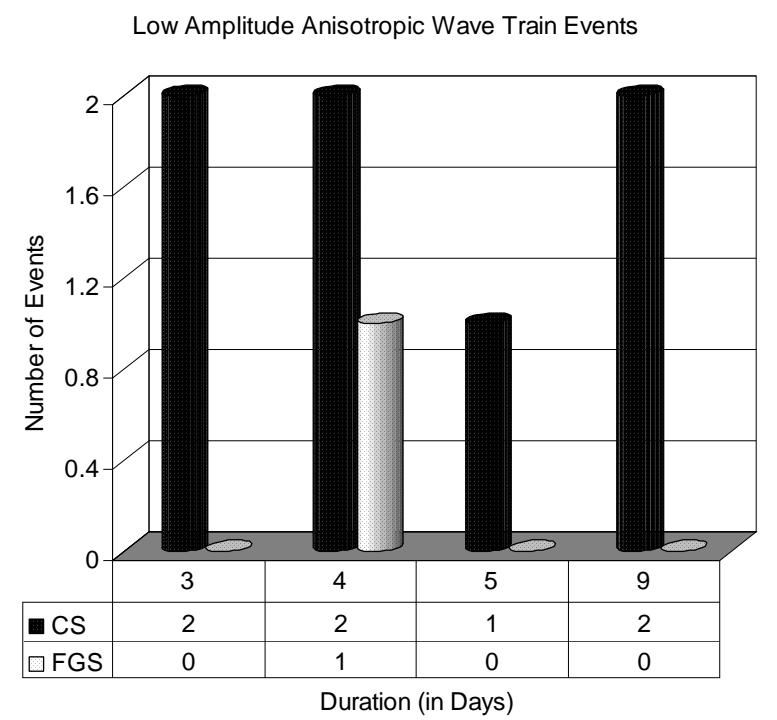

Fig. 1. Frequency histogram of high-speed solar wind streams according to their duration in days: corotating and flare-generated for LAEs in 1981-1994.

To study the effect of these streams on LAE, we have adopted the mentioned Chree analysis for days -5 to +5 and plotted as a percent deviation of cosmic ray nucleonic intensity data along with statistical error bars (I) for Deep River for the period 1981-1994 during LAE (see Fig. 2a,b). The deviation for each event was obtained from the overall average of 11 days. The epoch day (a zero day) corresponds to the starting days of high-speed solar wind streams. As depicted in Fig. 2a, the decrease in the cosmic ray intensity starts from -4 day and reaches its minimum on the zero epoch days, i.e. at the onset of a flare-generated stream, and then it starts increasing up to +2 day. At the same time, as seen from Fig. $2 b$, a significant decrease in the cosmic ray nucleonic intensity starts from -5 day during a co- 
rotating stream and reaches its mini-mum at the onset of stream (i.e. on the epoch day) and then increases statistically up to +5 day.
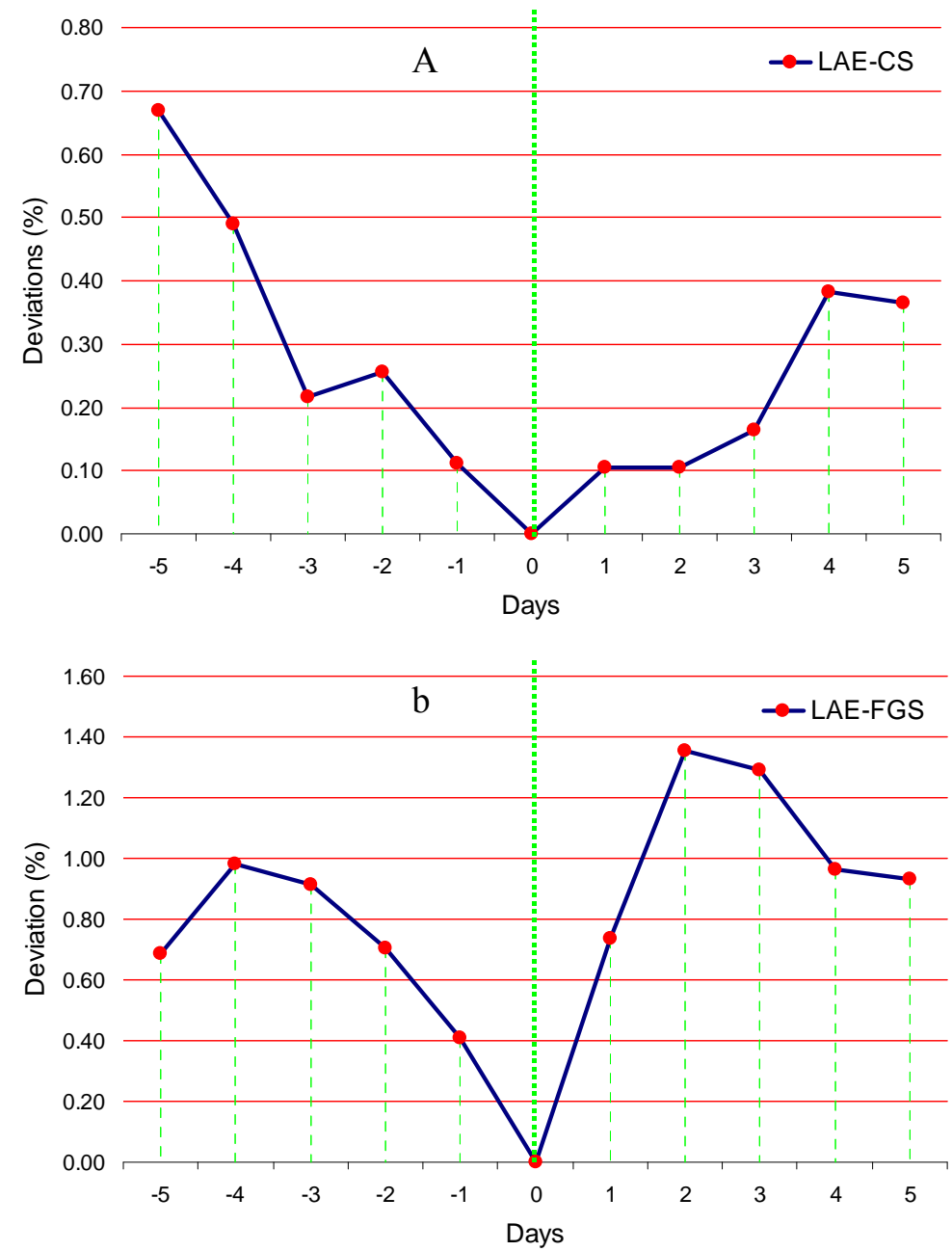

Fig. 2. The results of Chree analysis of superposed epoch from -5 to +5 days with respect to zero epoch days for LAEs along with statistical error bars (I) during (a) corotating and $(b)$ flare-generated streams in 1981-1994.

Thus we observed that at the onset of both types of streams the cosmic ray intensity nucleonic reaches its minimum during LAEs and then increases statistically. It is also evident that both the types of streams produce significant deviation in the cosmic ray nucleonic intensity during LAE. We therefore may conclude that both types of solar wind streams produce significant deviations in the cosmic ray nucleonic intensity during LAE. Shrivastava and Jaiswal [19] and Shrivastava [20] reported almost equal influence of flare-generated and corotating solar wind streams on the cosmic ray transient decreases.

Badruddin [21] studied the two classes - coronal-hole and solar-flareassociated streams - along with the observed heliospheric plasma and field parameters of these streams (speed, field strength, its variance, etc.) in a systematic manner in order to see their effects in the cosmic ray modulation. He found that 
flare-associated streams are much more effective in modulation than streams from coronal holes. However, since the possibility exists that solar wind structures during two types of streams might be different, the field variance appears to be the most critical parameter responsible for this difference in their effectiveness in modulation.

Sabbah [22] studied the behavior of cosmic rays observed by three stations (covering the median rigidity range 16-164 GV) during the time of high-speed solar-wind events. This author also studied the influence of the interplanetary magnetic field associated with HSSW. He reported that both the cosmic-ray intensity and the geomagnetic activity are enhanced by coronal-mass-ejection events. Sabbah [22] argued that the IMF magnitude and fluctuation are responsible for the depression of cosmic-ray intensity during HSSW events and that this depression is rigidity-dependent. Low-energy cosmic rays suffer more intensity depression. The rigidity spectrum of the $\mathrm{CR}$ intensity decreases is depending upon the phase of the solar cycle.

\section{CONCLUSIONS}

From the present study the following conclusions may be drawn:

- At the onset of both types of streams the cosmic ray nucleonic intensity reaches its minimum during low-amplitude events and then increases statistically.

- The two types of solar wind streams (corotating and flare-generated) produce significant deviations in the cosmic ray nucleonic intensity during lowamplitude anisotropic wave train events.

\section{ACKNOWLEDGEMENTS}

The authors are indebted to various experimental groups, in particular, Prof. Margret D. Wilson, Prof. K. Nagashima, Miss. Aoi Inoue and Prof. J.H. King for providing the data. We also acknowledge the use of NSSDC OMNI database and NGDC geophysical data. The authors are also very much thankful to the anonymous referees for their useful comments/suggestions. We would also like to thank to Dr. A.K. Mandal, Director, Tropical Forest Research Institute, Jabalpur for providing the research facilities in the department in a very liberal manner.

\section{REFERENCES}

1. Iucci, N., Parisi, M., Storini, M., \& Villoresi, G. (1979). Nuovo Cimento 2C 421.

2. Venkatesan, D., Shukla, A.K., Agrawal, S.P. (1982). Solar Phys. 81375.

3. Mavromichalaki, H., Vassilaki, A., \& Martmatsouri, E. (1988). Solar Phys. 115345.

4. Lindblad, B.A., Lundstedt, \& H., Larsson, B. (1989). Solar Phys. 120145.

5. Shukla, J.P., Shukla, A.K., Singh, R.L., \& Agrawal, S.P. (1979). Ind. J. Rad. And Space Phys. 8230.

6. Yadav, R.S., Sharma, N.K., \& Badruddin (1994). Solar Phys. 151393.

7. Jadhav, D. K., Shrivastava, M., Tiwari, A.K., \& Shrivastava, P.K. (1983) 18th Int. Cosmic Ray Conf. Bangalore 3, 337.

8. Kumar, S., Chauhan, M.L. (1996a). Ind. J. Radio \& Space Phys. 25106.

9. Kumar, S., Chauhan, M.L. (1996b.) Ind. J. Radio \& Space Phys. 25232. 
10. Kumar, S., Chauhan, M.L., \& Dubey S.K. (1997). Solar Phys. 176, 403.

11. Mishra, Rajesh K. (2006). Ph. D. thesis, Rani Durgawati University Jabalpur (M.P.) INDIA.

12. Kumar, S., Mishra, Rajesh, K., Mishra Rekha, A., \& Dubey, S.K. (2005). 29th Int. Cosmic Ray Conf. Pune 269.

13. King, J. (1983). Interplanetary Medium Data Book-Supplement 2, NSSD/WDC-A, Goddard Space Flight Centre, Greenbelt, Maryland,

14. King, J. (1986a). Interplanetary Medium Data Book-Supplement 3, NSSD/WDC-A, Goddard Space Flight Centre, Greenbelt, Maryland.

15. King, J. (1986b). Interplanetary Medium Data Book-Supplement 3A, NSSD/WDC-A, Goddard Space Flight Centre, Greenbelt, Maryland.

16. King, J. (1989). Interplanetary Medium Data Book-Supplement 4, NSSD/WDC-A, Goddard Space Flight Centre, Greenbelt, Maryland.

17. King, J., \& Papitashvili N.E. (1994). Interplanetary Medium Data Book, NSSCD/WDC-A-R@S94-08, Goddard Space Flight Centre, Greenbelt, Maryland.

18. Mavromichalaki, H., Vassilaki, A., \& Marmatsouri, E. (1988) .Solar Phys. 115, 345.

19. Shrivastava, P.K., Jaiswal, K.L. (2003). Solar Phys. 214195.

20. Shrivastava, P.K. (2003). 28th Int. Cosmic Ray Conf., Tsukaba 33731.

21. Badruddin (1996). Astrophys. and Space Sci. 246 (2) 171.

22. Sabbah (2000). Can. J. Phys./Rev. Can. phys. 78 (4) 293.

\section{KOSMISKĀ STAROJUMA NUKLEONU INTENSITĀTE MAZU AMPLITŪDU DIENĀS SPĒCİGU SAULES VĒJU LAIKĀ}

Rekha Agarwal, Rajesh K. Mishra, Sharad Tiwari

Kopsavilkums

Viena no Saules vēja pārsteidzošākajām īpatnībām ir tā, ka veidojas divu tipu plūsmas - liela un maza ātruma plūsmas. Noteikts, ka nonākot uz Zemes liela ātruma Saules vēja plūsmām, rodas geomagnētiskās vētras. Ātri darb̄̄gās plazmu plūsmas ir galvenie elementi, kas izsauc geomagnētisko darbību saistîtu ar Saules darbību, un tāpēc ir liela interese par Zemes fiziku un Sauli. Šie ātrdarbīgās plūsmas divi tipi tiek klasificēti divās kategorijās, kuru pamatā ir magnētisko lauku un Saules vēja parametri. Mēs pētījām kosmiskā starojuma depresiju saistīibā ar ātrdarbīgām Saules vēja plūsmām mazu amplitūdu dienās.

Kosmisko staru intensitātes dati analizēti no Saules vēja ātri darbīgo plūsmu parādīšanās sākuma. Saules vēja divu tipu plūsmas rada būtisku novirzi kosmiskā starojuma intensitātē mazu amplitūdu laikā. Sākumā kosmiskā starojuma intensitāte sasniedz minimumu mazu amplitūdu dienās, bet pēc tam palielinās statistiski.

10.08.2007. 